\title{
Cerebrovascular Accident and Snake Envenomation: A Scoping Study
} Mohammed Al-Sadawi ${ }^{1}$, Maliheh Mohamadpour ${ }^{1}$, Angelina Zhyvotovska ${ }^{1}$, Tahir Ahmed ${ }^{1,2}$, Joshua Schechter ${ }^{2}$, Yasmin Soliman ${ }^{1}$ and Samy I. McFarlane ${ }^{1, *}$

${ }^{1}$ Division of Cardiovascular Disease, Department of Internal Medicine, State University of New York, Downstate Medical Center, Brooklyn, NY 11203, USA

${ }^{2}$ Department of Emergency Medicine State University of New York, Downstate Medical Center, Brooklyn, New York, USA

\begin{abstract}
Background: Snake envenomation is associated with serious complications including infections, bleeding and, in rare occasions, thrombosis. Previous work by our group examined the association of snakebite and acute myocardial infarction. In this systematic review we aim to assess the clinical characteristics and outcomes of acute cerebrovascular accidents that are reported to be extremely rare complications of snake envenomation.
\end{abstract}

Methods: We performed a literature search for reports on stroke associated with snake envenomation between Jan 1995 to Oct 2018, and summarized their characteristics.

Results: Eighty-three published cases were reviewed. $66.3 \%$ of the cases were younger than 50 years of age. The mean time for the onset of the symptoms is $23.8 \pm 10.9$ hours after exposure. $77.1 \%$ of the cases found to have ischemic stroke, $20.5 \%$ with intra-cranial hemorrhage and both infarction and hemorrhage in $2.4 \%$. Mortality was reported in $16.9 \%$ with mean time between onset of the symptoms and death is 4.2 days.

Conclusion: Stroke secondary to snake envenomation is a rare but serious complication. Once stroke is suspected, initiating appropriate management is crucial in reducing morbidity and mortality associated with this potentially fatal complication of snake envenomation.

\section{Introduction}

Snake bite is one of the causes of stroke that has been reported less frequently. According to WHO, annual rate of snake bites have been estimated 5.4 million worldwide. Proximately 81000-138000 deaths have been reported annually. Most common affected population is among young adults and children in Africa, Asia and Latin America [1]. According to Center of Disease Control (CDC), annual rate of snake bite in the United States is 7,000-8,000 with about 5 deaths. The most common species in the United States reported by Central of Disease Control (CDC) includes rattlesnakes, copperheads, cottonmouths/water moccasins, and coral snakes [2]. In a Sri Lanka case series, the incidence of post-bite ischemic stroke was reported 9 in 500 bites [3].

Different Snake venoms contain different types of enzymes such as phospholipase A2, acetylcholinesterase, hyaluronidase, and metalloproteinases; such enzymes that have either direct neurotoxic or procoagulant or anticoagulation effects [4]. Therefore, These enzymes predisposing for causing either cerebral infarction due to cerebral hypoperfusion (watershed infarct), thrombotic occlusion of large vessels, vasculitis, consumption coagulopathy, or cardiogenic brain embolism; or hemorrhagic stroke $[5,6]$.

Depending on the enzyme content in the venom, the procoagulation versus anticoagulation activities can be prominent. For Instance, viper and colubrid venoms contain metalloproteinases, serine proteases, and C-type lentins with either agonist or antagonist platelet aggregation activity while the venom of elapids contains phospholipase A2 and three-finger proteins, which acts as an neurotoxins in neuromuscular junction [7].

There are few case series reporting snakebite related strokes with detailed information regarding the type of the venom and the type of stroke. Previous work by our group examined the association of snakebite and acute myocardial infarction [8]. In this study, we

\section{Publication History:}

Received: December 22, 2018

Accepted: April 09, 2019

Published: April 11, 2019

\section{Keywords:}

Snake Envenomation, Stroke, Cerebrovascular accident reviewed different case reports and series of snake envenomation associated with stroke and the outcome.

\section{Methods}

On October 2018, a systematic search was conducted using PubMed and Google Scholar to review case reports about stroke caused by snake envenomation from January 1995 to October 2018. Studies that listed the keywords "snake, envenomation, stroke, cerebrovascular accidents" were used to identify case reports of stroke associated with snake envenomation. The reference list of each report was checked for additional cases. Data reviewed included demographic data, cardiovascular risk factors, snake species, computed tomography of the head, magnetic resonance of the head, time of presentation, complications, management, and outcome.

\section{Results}

83 cases were identified (Table 1) [9-79]. The patients were in the age group of 5 to 80 years and the mean age was $40 \pm 17.5$ years, median age was 40 years and $66.3 \%$ of the cases were younger than 50 years of age. $68.7 \%$ of the cases were reported for males and $31.3 \%$ for females. Diabetes Mellites and hypertension were reported only in 2 cases (2.4\%). Snake Species are represented in (Figure 1); however, about $30 \%$ of the cases did not mention snake species. $30 \%$ of the

*Corresponding Author: Prof. Samy I. McFarlane, Divisions of Cardiovascular Disease, and Endocrinology, Department of Internal Medicine, State University of New York, Downstate Medical Center, Brooklyn, New York,11203, USA, Tel: 718270-6707, Fax: 718-270-4488; E-mail: smcfarlane@downstate.edu

Citation: Al-Sadawi M, Mohamadpour M, Zhyvotovska A, Ahmed T, Schechter J, et al. (2019) Cerebrovascular Accident and Snake Envenomation: A Scoping Study. Int J Clin Res Trials 4: 133. doi: https://doi.org/10.15344/2456-8007/2019/133

Copyright: (C) 2019 Al-Sadawi et al. This is an open-access article distributed under the terms of the Creative Commons Attribution License, which permits unrestricted use, distribution, and reproduction in any medium, provided the original author and source are credited. 
Citation: Al-Sadawi M, Mohamadpour M, Zhyvotovska A, Ahmed T, Schechter J, et al. (2019) Cerebrovascular Accident and Snake Envenomation: A Scoping Study. Int J Clin Res Trials 4: 133. doi: https://doi.org/10.15344/2456-8007/2019/133

Page 2 of 7

\begin{tabular}{|c|c|c|c|c|c|c|}
\hline Name/Year & Age /Sex & GCS & Symptoms & Onset (hours) & Affected area on CT/MRI & Outcome (Days) \\
\hline Sahoo AK, 2018 & $36 / \mathrm{M}$ & 6 & Rt H, aphasia & 18 & Lt MCA & Full Recovery \\
\hline Sahoo LK, 2018 & $36 / \mathrm{M}$ & 8 & Rt $\mathrm{H}$, aphasia, $\mathrm{O}$ & 1 & $\begin{array}{l}\text { Lt frontotemporal, Rt basal ganglia, Rt } \\
\text { thalamus, occipital, cerebellum }\end{array}$ & Sequalae \\
\hline Kutiyal, 2018 & $26 / \mathrm{M}$ & 6 & Locked-in syndrome & 2 & & Full Recovery \\
\hline Pothukuchi, 2018 & $55 / \mathrm{M}$ & 15 & expressive aphasia & 1 & bilateral frontal lobes & Sequalae \\
\hline Bakare, 2018 & $27 / M$ & 15 & seizures, Rt H & 2 & Lt parieto-occipital ICH & Full Recovery \\
\hline \multirow[t]{2}{*}{ Pothukuchi, 2017} & $70 / \mathrm{M}$ & 15 & Rt H, seizures & 96 & Lt capsuloganglionic & Full Recovery \\
\hline & $55 / \mathrm{M}$ & 15 & Lf $\mathrm{H}$, aphasia & 168 & bilateral frontal lobes & Full Recovery \\
\hline Rathnayaka, 2017 & $43 / \mathrm{M}$ & 9 & Rt H, seizures & 0.75 & Lt ICH, sub falcine herniation & Death [11] \\
\hline Delgado, 2017 & $58 / \mathrm{M}$ & 8 & Lf $H$, seizures & 4 & Rtnucleocapsular ICH & Sequalae \\
\hline Oliveira, 2017 & $59 / \mathrm{F}$ & 3 & coma & 3.5 & SAH, ICH & Death [3] \\
\hline Janardanaaithala, 2017 & $38 / \mathrm{F}$ & 6 & coma, abulia & 2.5 & Lt capsuloganglionic, cerebellum & Sequalae \\
\hline Swati, 2017 & $80 / \mathrm{M}$ & 15 & Lt H & 2 & ICH Rt parietal, occipital/ Lt PICA & Sequalae \\
\hline Paul, 2017 & $75 / \mathrm{M}$ & 10 & Rt $\mathrm{H}, \mathrm{P}$ & 24 & bilateral cerebellar, Rttemporooccipital & Sequalae \\
\hline Krishna, 2017 & $30 / \mathrm{F}$ & 15 & seizures, Rt H & 4 & Lt capsuloganglionic & Full Recovery \\
\hline Pal, 2017 & $21 / \mathrm{M}$ & 0 & Lt $\mathrm{H}$, facial palsy & 48 & Rt MCA & Sequalae \\
\hline Abdul Jalal, 2017 & $48 / \mathrm{M}$ & 13 & Lt H, P & 1 & ICH Lt frontal, temporal & Full Recovery \\
\hline Cañas, 2016 & $48 / \mathrm{F}$ & 8 & Coma, hypotonia, $\mathrm{P}$ & 96 & Basilar artery & Death [3] \\
\hline Silveira, 2016 & $52 / \mathrm{M}$ & 13 & dizziness & 24 & $\mathrm{ICH}$ & Full Recovery \\
\hline Ajit, 2016 & $30 / \mathrm{F}$ & 15 & $\begin{array}{l}\text { Lt } H \text {, facial palsy, } \\
\text { aphasia }\end{array}$ & 48 & Lt fronto-tempo-parietal & Sequalae \\
\hline Prabhu, 2016 & $45 / \mathrm{F}$ & 3 & coma, Lt H, P & 3 & $\begin{array}{l}\text { bilateral cerebellum, thalami, frontal } \\
\text { and parietal, Rt temporal, midbrain }\end{array}$ & Sequalae \\
\hline Jeyaraj, 2016 & $28 / \mathrm{F}$ & 15 & P, O, facial palsy, Lt H. & & $\begin{array}{l}\text { Bilateral cerebellar, midbrain, left } \\
\text { thalamic with ICH }\end{array}$ & Full Recovery \\
\hline Ghezala, 2015 & $37 / \mathrm{M}$ & 6 & $\begin{array}{l}\text { O, decerebration } \\
\text { rigidity }\end{array}$ & 4 & Subdural hematoma, ICH & Death \\
\hline Pardal, 2015 & $10 / \mathrm{M}$ & 15 & Rt H & 25 & ICH Rt frontal & Sequalae \\
\hline \multirow[t]{2}{*}{ Gunchan, 2014} & $36 / \mathrm{M}$ & 7 & Rt, coma & 24 & basilar artery & Sequalae \\
\hline & $40 / \mathrm{M}$ & 15 & Broca's aphasia & 9 & superior division of Lt MCA with ICH & Sequalae \\
\hline \multirow[t]{3}{*}{ Rebahi, 2014} & $32 / \mathrm{F}$ & 8 & coma & 3 & frontal, temporal, parietal & Death [5] \\
\hline & $5 / \mathrm{F}$ & 8 & coma & 96 & Rt frontal temporo-parieto-occipital & Death [7] \\
\hline & $51 / \mathrm{M}$ & 10 & coma, Rt H & 48 & bilateral internal capsules & Full Recovery \\
\hline \multirow[t]{2}{*}{ Bush, 2014} & $50 / \mathrm{M}$ & 8 & $\begin{array}{l}\text { Aphasia, Rt H, facial } \\
\text { palsy }\end{array}$ & 11 & Rt frontal, Lt parietal, lt occipital & Death [3] \\
\hline & $17 / \mathrm{M}$ & 15 & Facial palsy, Lt H & 73 & $\begin{array}{l}\text { Rtsylvian, Rt cerebellum, bilateral } \\
\text { frontal, occipital }\end{array}$ & Sequalae \\
\hline Mahale, 2014 & $58 / \mathrm{M}$ & 15 & $\begin{array}{l}\text { bilateral homonymous } \\
\text { hemianopia }\end{array}$ & 48 & Bilateral occipital & Sequalae \\
\hline Gopalan, 2014 & $32 / \mathrm{F}$ & 8 & Rt H & 6 & Lt MCA, Lt ACA, Lt ICA & Sequalae \\
\hline Chandrashekar, 2014 & $40 / \mathrm{F}$ & 15 & Rt H, aphasia & 6 & Lt tempero-parietal & Sequalae \\
\hline Kumar, 2014 & $22 / \mathrm{M}$ & 8 & coma & 144 & ICH Lt parietal & Sequalae \\
\hline Vale, 2013 & $16 / \mathrm{M}$ & 8 & $\begin{array}{l}\text { top-of-the-basilar } \\
\text { syndrome }\end{array}$ & 24 & $\begin{array}{l}\text { bilateral occipital, Lt temporal, } \\
\text { cerebellum }\end{array}$ & Sequalae \\
\hline Bhatt, 2013 & $65 / F$ & 10 & Aphasia, Rt H & 5 & $\begin{array}{l}\text { Lt precentral, postcentral, hemipons, } \\
\text { cerebellum }\end{array}$ & Sequalae \\
\hline Das, 2013 & $27 / \mathrm{F}$ & 15 & $\begin{array}{l}\text { Gerstmann's syndrome, } \\
\mathrm{P}\end{array}$ & 6 & $\begin{array}{l}\text { Lt parietofrontal, Lt lateral sinus } \\
\text { thrombus }\end{array}$ & Sequalae \\
\hline
\end{tabular}

Continue... 
Citation: Al-Sadawi M, Mohamadpour M, Zhyvotovska A, Ahmed T, Schechter J, et al. (2019) Cerebrovascular Accident and Snake Envenomation: A Scoping Study. Int J Clin Res Trials 4: 133. doi: https://doi.org/10.15344/2456-8007/2019/133

Page 3 of 7

\begin{tabular}{|c|c|c|c|c|c|c|}
\hline Aissaoui, 2013 & $72 / \mathrm{M}$ & 15 & Aphasia, Lt hemianopsia & 48 & Lt occipito-temporoparietal & Full Recovery \\
\hline Saha, 2013 & $32 / \mathrm{M}$ & 9 & aphasia, Rt H & 6 & Lt MCA & Sequalae \\
\hline Ittyachen, 2012 & $55 / \mathrm{M}$ & 12 & Coma & 5 & bilateral thalamic & Sequalae \\
\hline Chani, 2012 & $55 / \mathrm{M}$ & 10 & AMS & 12 & bifocal & Sequalae \\
\hline Jeevagan, 2012 & $65 / \mathrm{M}$ & 15 & Lt H & 12 & Rt parietal & Sequalae \\
\hline Gupta, 2012 & $48 / \mathrm{F}$ & 11 & AMS & 48 & Lt cerebellar & Full Recovery \\
\hline Gouda, 2011 & $40 / \mathrm{F}$ & 9 & AMS, hypotonia & 1 & bilateral cerebellar, occipital & Sequalae \\
\hline Anim, 2011 & $48 / \mathrm{F}$ & 10 & AMS & 20 & Rt cerebellar, medulla, pons & Death [7] \\
\hline Sathishkuma, 2011 & $45 / \mathrm{M}$ & 5 & Lt H, AMS & 4 & Rt MCA & Sequalae \\
\hline Vale, 2010 & $24 / \mathrm{M}$ & 15 & Lt $\mathrm{H}$, right homonymous hemianopsia & 6 & Rt MCA & Sequalae \\
\hline Machado, 2010 & $62 / \mathrm{F}$ & 15 & Rt H & 2 & Lt MCA with ICH & Sequalae \\
\hline Anim, 2010 & $32 / \mathrm{M}$ & 9 & AMS, O & 24 & & Sequalae \\
\hline Narang, 2009 & $18 / \mathrm{M}$ & 15 & Aphasia, Rt H & 24 & Lt MCA & Sequalae \\
\hline Hoskote, 2009 & $24 / \mathrm{M}$ & 8 & coma, akinetic mute & 5 & bilateral ACA & Sequalae \\
\hline \multirow[t]{9}{*}{ Gawarammana, 2009} & $56 / \mathrm{M}$ & 13 & $\mathrm{P}, \mathrm{O}$ & 7 & Cerebellum, bilateral frontal, parietal & Full Recovery \\
\hline & $37 / \mathrm{M}$ & 14 & $\mathrm{P}, \mathrm{O}, \mathrm{Lt} \mathrm{H}$ & $<1$ & Rt parietal, lentiform nucleus & Full Recovery \\
\hline & $45 / \mathrm{F}$ & 14 & $\mathrm{P}, \mathrm{O}, \mathrm{Lt} \mathrm{H}$ & 96 & Rt frontal, Rt cerebellum & Full Recovery \\
\hline & $45 / \mathrm{F}$ & 10 & $\mathrm{P}, \mathrm{O}$ & $<1$ & Lt caudate, bilateral occipital & Sequalae \\
\hline & $8 / \mathrm{M}$ & 6 & $\mathrm{P}, \mathrm{O}$ & $<1$ & bilateral MCA & Death [5] \\
\hline & $53 / \mathrm{M}$ & 14 & $\mathrm{P}, \mathrm{O}$ & 2 & Multiple cortical and cerebellum & Sequalae \\
\hline & $35 / \mathrm{M}$ & 9 & $\mathrm{P}, \mathrm{O}$ & $<1$ & Lt frontal & Sequalae \\
\hline & $39 / \mathrm{M}$ & 13 & $\mathrm{P}, \mathrm{O}$ & $<1$ & Multiple cerebellum and occipital & Sequalae \\
\hline & $54 / \mathrm{M}$ & 15 & $\mathrm{P}, \mathrm{O}$ Lt H & 2 & Rt parietal-temporal & Sequalae \\
\hline Mugundhan, 2008 & $14 / \mathrm{M}$ & 8 & $\mathrm{P}, \mathrm{O}$ & $<1$ & bilateral cerebellar, Rt occipital & Death [1] \\
\hline \multirow[t]{2}{*}{ Prakash, 2008} & $40 / \mathrm{M}$ & 3 & $\mathrm{P}, \mathrm{O}$, Locked in syndrome & 3 & & Full Recovery \\
\hline & $25 / \mathrm{M}$ & 3 & $\mathrm{P}, \mathrm{O}$, Locked in syndrome & 6 & & Full Recovery \\
\hline Santos-Soares, 2007 & $65 / F$ & 8 & Aphasia, Rt H, Lt facial palsy & 12 & ICH Lt temporo-parietal & Full Recovery \\
\hline Das, 2007 & $22 / \mathrm{F}$ & 15 & Aphasia, Rt H & 36 & multiple Lt cerebral & Sequalae \\
\hline \multirow[t]{3}{*}{ Thomas, 2007} & $46 / \mathrm{M}$ & 15 & Lt inferior quadranopsia & 22 & bilateral occipital & Full Recovery \\
\hline & $55 / \mathrm{M}$ & 15 & Rt H, aphasia & 36 & Lt MCA & Sequalae \\
\hline & $66 / \mathrm{M}$ & 13 & Lt H, left homonymous hemianopsia & 24 & Multiple cortical & Sequalae \\
\hline Merle, 2005 & $46 / \mathrm{M}$ & 15 & Lt lateral homonymous quadranopsia & 24 & Occipital & Full Recovery \\
\hline Anim, 2004 & $20 / \mathrm{F}$ & 15 & decreased visual acuity & 24 & & Sequalae \\
\hline Lee, 2004 & $72 / \mathrm{M}$ & 7 & Rt H & 72 & ACA, MCA, subacute PICA & Sequalae \\
\hline Bartholdi, 2004 & $22 / \mathrm{M}$ & 15 & Monoparesis of the Lt leg & 24 & ICH Rt parasagittal & Sequalae \\
\hline Boviatsis, 2003 & $65 / F$ & 13 & Lt H, Rthemianopsia & 4 & Multiple cerebral & Full Recovery \\
\hline Zhang, 2003 & $22 / \mathrm{M}$ & 3 & Rtanisocoria & 11 & ICH with herniation & Death [2] \\
\hline Hung, 2003 & $52 / \mathrm{M}$ & 15 & Monoparesis of the Lt arm & 24 & $\begin{array}{l}\text { bilateral fronto-parieto-occipital, Rt } \\
\text { thalamus }\end{array}$ & Death [3] \\
\hline Diaz, 2003 & $11 / \mathrm{M}$ & 13 & Rt facial palsy, lt $\mathrm{H}$ & 2 & Rt MCA & Sequalae \\
\hline Numeric, 2002 & $32 / \mathrm{M}$ & 15 & Lt H, Rt Facial palsy, Wernicke's aphasia & 144 & Rt ACA & Sequalae \\
\hline Pinho, 2001 & $64 / \mathrm{F}$ & 8 & coma, anisocoria & 15 & $\mathrm{ICH}$ & Full Recovery \\
\hline Lee, 2001 & $54 / \mathrm{F}$ & 15 & one and-a-half syndrome & 4 & Proximal basilar artery & Sequalae \\
\hline Panicker, 2000 & $21 / \mathrm{M}$ & 15 & Motor aphasia, Rt H & 2 & Lt frontal & Sequalae \\
\hline Singh, 1998 & $23 / \mathrm{M}$ & 12 & coma & 36 & Rt frontal, parietal, occipital & Death [4] \\
\hline Medytt, 1998 & $57 / \mathrm{M}$ & 11 & coma & $<1$ & Bilateral ICH & Death [1] \\
\hline Cole, 1996 & $43 / \mathrm{M}$ & 14 & $\begin{array}{l}\text { Wernicke aphasia, alexia, uadrantanopia, } \\
\text { Rt H }\end{array}$ & 24 & Lt temporal with ICH & Sequalae \\
\hline
\end{tabular}

Table 1: Cases reported with snake envenomation associated with stroke [9-78].

GCS: Glasgow Coma Scale, CT: Computed Topography, MRI: Magnetic Resonance Imaging, M: Male, F: Female, Lt: Left, Rt: Right, H: Hemiplegia,

O: Ophthalmoplegia, P: Ptosis, AMS: Altered Mental Status, ICH: Intra-Cranial Hemorrhage, MCA: Middle Cerebral Artery, ACA: Anterior

Cerebral Artery, ICA: Internal Carotid Artery, PICA: Posterior Inferior Cerebral Artery 
Citation: Al-Sadawi M, Mohamadpour M, Zhyvotovska A, Ahmed T, Schechter J, et al. (2019) Cerebrovascular Accident and Snake Envenomation: A Scoping Study. Int J Clin Res Trials 4: 133. doi: https://doi.org/10.15344/2456-8007/2019/133

Page 4 of 7

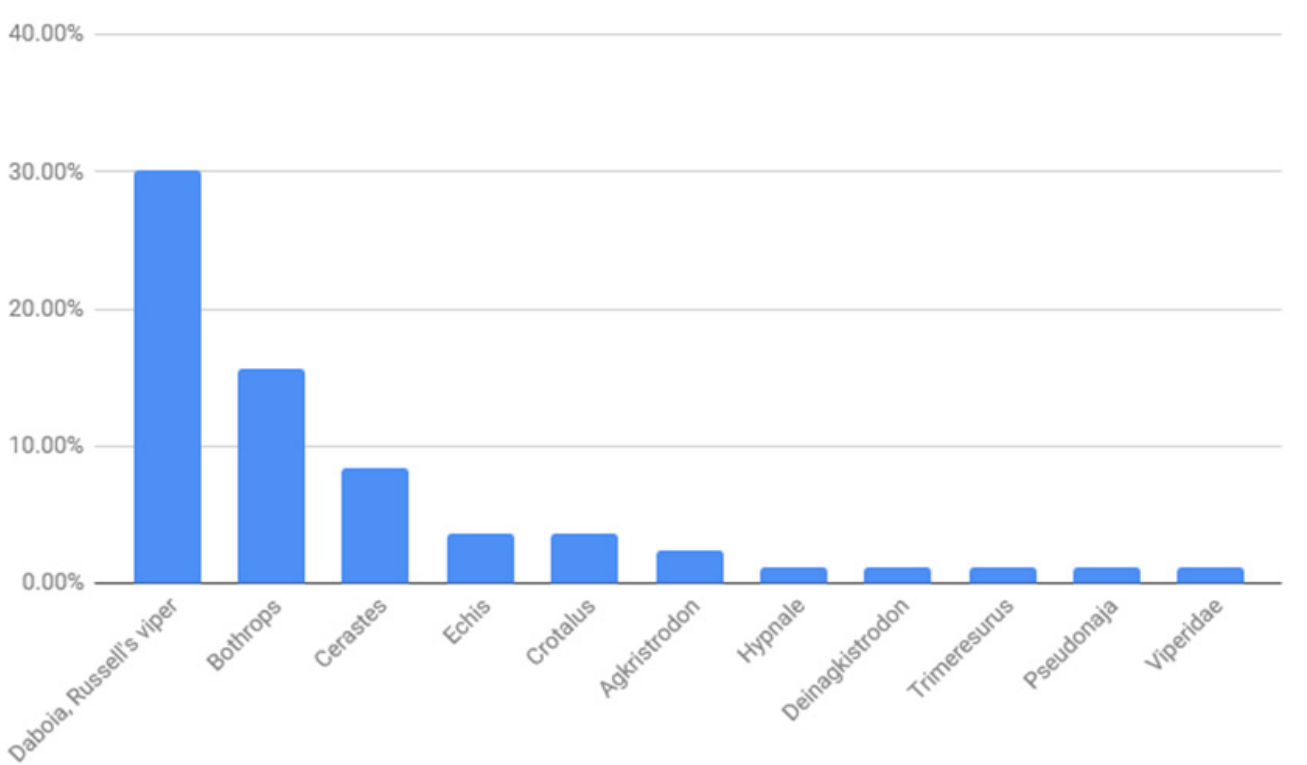

Figure 1: Frequency of Stroke envenomation by species. Note: $30 \%$ of the cases had no information regarding snake species.

cases reported with Daboia, Russell's viper, species. $83.1 \%$ of the cases were bitten in their legs and $16.9 \%$ were bitten in hands. All the cases were managed by anti-snake venom, in $27.7 \%$ of the cases the symptoms started after receiving anti-snake venom. $19.3 \%$ of the cases also treated with antiplatelet and $3.6 \%$ were treated with craniotomy. The mean time for the onset of the symptoms is $23.8 \pm 10.9$ hours after exposure. $77.1 \%$ of the cases found to have ischemic stroke, $20.5 \%$ with intra-cranial hemorrhage and both infarction and stroke in $2.4 \%$.

Complications were reported in many cases: Altered mental status necessities intubation in $36.1 \%$ of the cases, acute kidney injury was reported in $12.2 \%$, pulmonary edema in $3.6 \%$, myocarditis in $1.2 \%$ and endocarditis in $1.2 \%$. The outcome of the cases showed full recovery in $26.5 \%$ with mean time needed for recovery 88.9 days. Mortality was reported in $16.9 \%$ mainly due to complication of stroke with mean time between onset of the symptoms and death is 4.2 days.

\section{Discussion}

Venomous snakes can cause stroke due to either their neurotoxic or hemotoxic enzymes [4]. However, type of stroke either hemorrhagic or ischemic depends on the venom enzyme-make up in each different snake species.

Ischemic strokes were $77.1 \%$ of the cases while ICH were $20.5 \%$. As reported, the most common species were Russell's vipers with higher incidence of ischemic stroke than intracranial hemorrhage (ICH). Whereas, reportedly Bothrops species were the second most common venoms to be reported with significantly more propensity towards ICH than ischemic stroke [3]. Most of the cases exposed to snake bites are young males $<50$ years old. Mortality rate was higher among Russell's vipers; however, Russell's vipers were the most commonly reported bite. There was single report of bite by Horned viper and Pseudonaja textilis with ICH; Cerastes and Deinagkistrodon envenomation were associated with large infarcts $[29,74,32,66]$.

The venom of Bothrops species contains metalloproteinases, type of hemotoxin that can cause hemolysis, thrombocytopenia, disseminated intravascular coagulation [76,77]. Among Borthrops, ICH was frequently reported in jararacussu, atrox, marajoensis species and infarcts was reported for lanceolatu species. Most of the patient who had bites were young and no comorbidity or risk factor for either hemorrhagic or ischemic stroke except $2 \%$ who had history of diabetesmellitus or hypertension.

Mortality was more common among those who either arrived in coma or required intubation due to AMS during the course of hospitalization. Death happened within the first 4.2 days after the exposure. Risk of mortality was amplified by $\mathrm{ICH}$, bilateral extensive cerebral, cerebellar infarction, mass effect, or post circulation occlusion.

However, all the cases received anti-venom once they sought medical care after exposure; while mean time for the onset of symptoms was $23.8 \mathrm{~h}$ after envenomation. In $27.7 \%$ of the cases symptoms started even after receiving antivenom which indicates the potency of the venom in causing stroke and the importance of early administration of anti-venom serum with consideration of other adjutant therapies. There are some animal studies indicating the critical and time sensitive usage of metalloproteinase inhibitors and antivenom would be the best approach to reduce hemorrhagic stroke after Bothrops species envenoming [78]. Studies have shown that single individual fractions of different venoms have failed to be lethal to mice in some studies even after $48 \mathrm{~h}$, whereas a corresponding concentration of whole crude venom have been sufficiently lethal within $10 \mathrm{~min}$. Synergistic action of venom component is important for designing more effective antivenoms [79]. In figure 2, we summarized the postulated mechanisms for cerebrovascular accidents following a snake envenomation.

Limited access to antivenom and also lack of awareness for seeking medical management shortly after snakebite to reduce the chance of cerebrovascular events and the other complications mainly in developing countries is an alarming medical emergency to be addressed. Therefore, WHO considered snake envenomation as category A neglected tropical diseases to maximize the efforts facing its complication [80]. 
Citation: Al-Sadawi M, Mohamadpour M, Zhyvotovska A, Ahmed T, Schechter J, et al. (2019) Cerebrovascular Accident and Snake Envenomation: A Scoping Study. Int J Clin Res Trials 4: 133. doi: https://doi.org/10.15344/2456-8007/2019/133

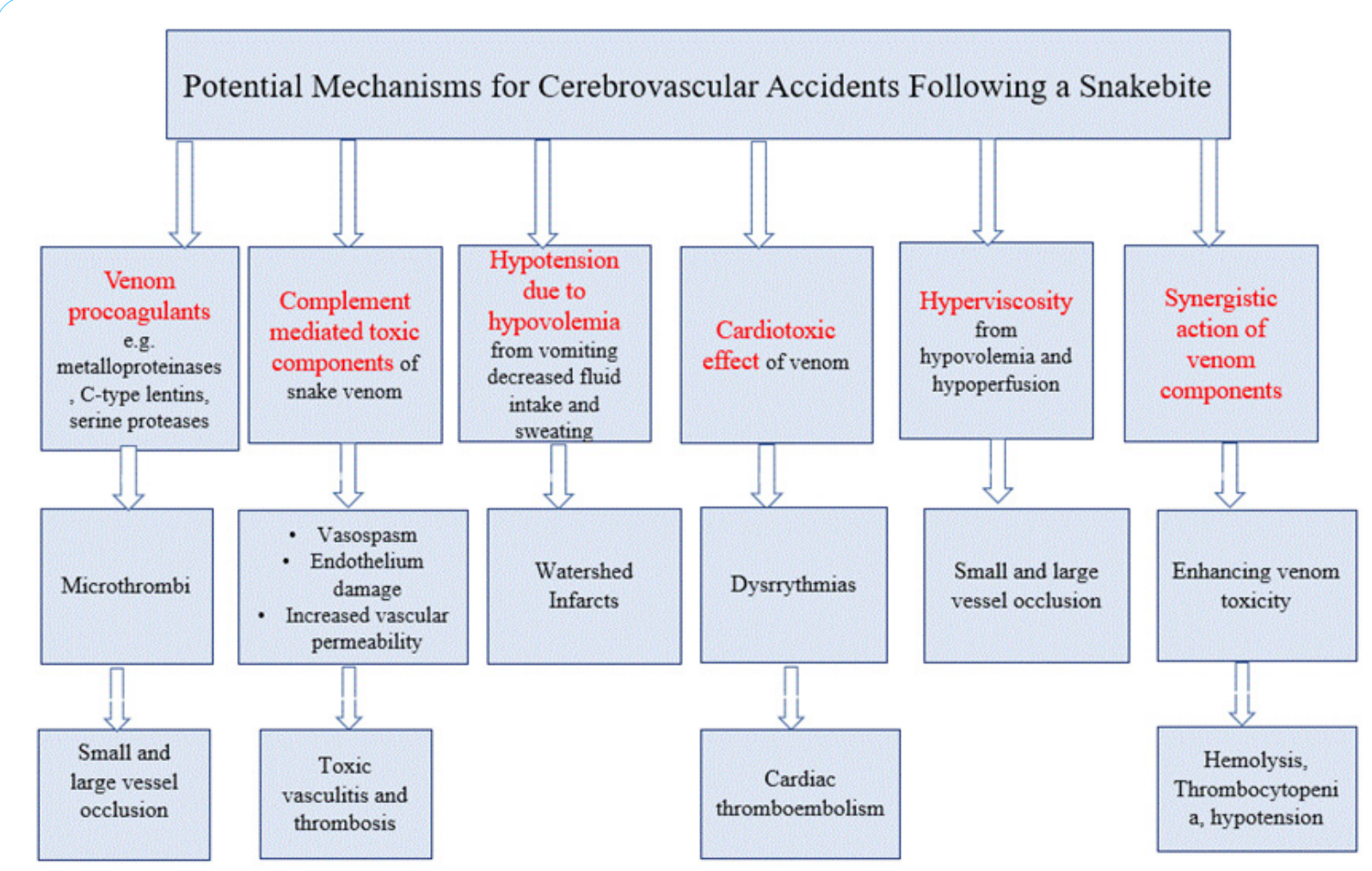

Figure 2: Postulated mechanisms for cerebrovascular accidents following a snake bite.

\section{Conclusion}

Stroke is a rare but rather serious complication of snake envenomation that is associated with high mortality rate. Further research is needed to elucidate the mechanisms of stroke in the context of snakebites thus paving the way for the development of specific therapeutic interventions. However, early administration of anti-venom serum with consideration of other adjutant therapies is crucial in snakebites in order to reduce the associated complications including strokes.

\section{Acknowledgements}

This work is supported, in part, by the efforts of Dr. Moro O. Salifu M.D., M.P.H., M.B.A., M.A.C.P., Professor and Chairman of Medicine through NIH Grant number S21MD012474.

\section{Competing Interests}

The authors declare no competing interests.

\section{References}

1. World Health Organization (2018) Facts sheets: WHO Snakebite envenoming

2. Center of Disease Control.

3. Thomas L, Tyburn B, Ketterlé J, Biao T, Mehdaoui H, et al. (1998) Prognostic significance of clinical grading of patients envenomed by Bothrops lanceolatus in Martinique. Soc Trop Med Hyg 92: 542-545.

4. Warrell DA (1996) Animal toxins. In: Cook GC, ed. Manson's tropical diseases. 20th ed. London: Saunders.
5. Del Brutto OH (2013) Neurological effects of venomous bites and stings: snakes, spiders, and scorpions. HandbClin Neurol 114: 349-368.

6. Panicker JN, Madhusudanan S (2000) Cerebral infarction in a young male following viper envenomation. J Assoc Physicians India 48: 744-745.

7. Del Brutto OH, Del Brutto VJ (2012) Neurological complications of venomous snake bites: a review. Acta Neurol Scand 125: 363-372.

8. Samy I McFarlane (2018) Myocardial Infarction after Snakebite Envenomation: A Scoping Study. SF J Cardiol 2:3.

9. Sahoo AK, Sriramka B (2018) Acute Reversible Ischemic Stroke after Snake Bite. Indian J Crit Care Med 22: 611-612.

10. Sahoo LK, Mallick AK, Mohanty G, Swain KP, Biswal NR, et al. (2018) A Rare Case of Stroke Due to Multiple Ischemic Infarctions following Russell's Viper Envenomation. Med J DY Patil Vidyapeeth 11: 57-58.

11. Kutiyal AS, Malik C, Hyanki G (2018) Locked-in syndrome post snake bite: a rare presentation. Trop Doct 48: 68-69.

12. Pothukuchi VK, Chepuri VR, Natta K, Madigani N, Kumar A, et al. (2017) A rare case report of Russell's viper snakebite with ischemic stroke. Hong Kong Journal of Emergency Medicine 25: 95-97.

13. Bakare AK, Wahab K, Ilesanmi O, Sanya E (2018) Intraparenchymal Intracerebral Hemorrhage Complicating Venomous Snakebite in Nigeria: A Case Report. Neurology 90: 6.235.

14. Pothukuchi VK, Kumar A, Teja C, Verma A (2017) Rare Case Series of Ischemic Stroke Following Russell's Viper Snake Bite in India. Acta Med Indones 49: 343-346.

15. Namal Rathnayaka RM, Kularatne SA, Kumarasinghe KD, Ranaweera J, Nishanthi Ranathunga $P E$, et al. (2017) Ischemic brain infarcts and intracranial haemorrhages following Russell's viper (Daboiarusselii) bite in Sri Lanka. Toxicon 125: 70-73.

16. Delgado ABT, Gondim CCVL, Reichert LP, da Silva PHV, Souza RMDCE, et al. (2017) Hemorrhagic stroke secondary to Bothrops spp. venom: A case report. Toxicon 132: 6-8.

17. Silva de Oliveira S, Freitas-de-Sousa LA, Alves EC, de Lima Ferreira LC, da Silva IM, et al. (2017) Fatal stroke after Bothrops snakebite in the Amazonas state, Brazil: A case report. Toxicon 138: 102-106. 
Citation: Al-Sadawi M, Mohamadpour M, Zhyvotovska A, Ahmed T, Schechter J, et al. (2019) Cerebrovascular Accident and Snake Envenomation: A Scoping Study. Int J Clin Res Trials 4: 133. doi: https://doi.org/10.15344/2456-8007/2019/133

Page 6 of 7

18. Janardanaaithala (2017) Thrombotic stroke following viper bite. University Journal of Medicine and Medical Sciences.

19. Swati AC, Arjun MD, Piyush AR (2017) Rare Snake Bite Sequelae: Intracerebral Haemorrhage with Cerebellar Infarction. International Journa of Contemporary Medical Researc.

20. Paul R, Sasane S (2017) Rare Ischemic Stroke Presentation after Viper Bite-A Case Report. Int.J Neurology Res.

21. Krishna PV, Ahmed S, Reddy KVN (2017) Ischemic stroke consequent to snake bite. J NTR Univ Health Sci 6: 192-193.

22. Pal J, Mondal S, Sinha D, Ete T, Chakraborty A, et al. (2014) Cerebra infarction: an unusual manifestation of viper snake bite. IJRMS 2: 3.

23. Thomas A, Varghese $P$, Jalal MJA (2017) Intracerebral Hemorrhage: A Rare Snake Bite Sequelae. Indian Journal of Neurosurgery 6: 27-30.

24. Cañas CA (2016) Brainstem ischemic stroke after to Bothropsatrox snakebite, Toxicon 120: 124-127.

25. Silveira GG, Machado CR, Tuyama M, Lima MA (2016) Intracranial Bleeding Following Bothrops sp. Snakebite. Neurologist 21: 11-12.

26. Ajit D, Kumar SG (2016) Acute Cerebral Infarct on Evolution in Middle Cerebral Artery Following Viper Snake Bite. ISSR.

27. Bhojaraja M, Prabhu MM, Stanley W, Sanket S, Marimuthu VKN, et al. (2016) Snake bite: An unusual cause of ischaemic stroke. AMJ 9: 138-141.

28. Jeyaraj M (2016) An interesting case of Ischemic stroke following snake bite University Journal of Medicine and Medical Sciences 2: 1.

29. Ghezala HB, Snouda S (2015) Accident vasculaire cerebral hémorragique mortel suite à une envenimation par une vipère à corne en Tunisie. Hemorrhagic stroke following a fatal envenomation by a horned viper in Tunisia. Pan Afr Med J 21: 156.

30. Pardal, Pinheiro, Silva, Santos, Gadelha. Hemorrhagic stroke in children caused by Bothropsmarajoensis envenoming: a case report. Journal of Venomous Animals and Toxins Including Tropical Diseases.

31. Paul G, Paul B, Puri S (2014) Snake bite and stroke: Our experience of two cases. Indian J Crit Care Med 18: 257-258.

32. Rebahi H, Nejmi H, Abouelhassan T, Hasni K, Samkaoui MA, et al. (2014) Severe Envenomation by Cerastescerastes Viper: An Unusual Mechanism of Acute Ischemic Stroke. J Stroke Cerebrovasc Dis 23: 169-172.

33. Bush SP, Mooy GG, Phan TH (2014) Catastrophic Acute Ischemic Stroke After Crotalidae Polyvalent Immune Fab (Ovine)-Treated Rattlesnake Envenomation. Wilderness Environ Med 25: 198-203.

34. Mahale R, Mehta A, Javali M, Srinivasa R (2014) A case of bilateral occipital lobe infarcts following Indian tree viper bite. J Stroke 16: 205-207.

35. Gopalan S, Ramadurai S, Bharathi L, Arthur P (2014) Ischaemic stroke with internal carotid artery occlusion following viper bite: A case report. Neurology Asia 19: 191-193.

36. Chandrashekar, Anikethana GV, Kalinga BE (2012) Viper Bite Presenting as Acute Ischemic Stroke. IJSR.

37. Kumar N, Mukherjee S, Patel MP, Shah KB, Kumar S, et al. (2014) A case of saw scale viper snake bite presenting as intraparenchymal haemorrhage: case report. Int J Health Sci Res 4: 333-337.

38. Vale TC, Leite AF, Hora PR, Coury MI, Silva RC, et al. (2013) Bilateral posterior circulation stroke secondary to a crotalid envenomation: case report. Rev Soc Bras Med Trop 46: 255-256.

39. Bhatt A, Menon AA, Bhat R, Ramamoorthi $K$ (2013) Myocarditis along with acute ischaemic cerebellar, pontine and lacunar infarction following vipe bite. BMJ Case Rep.

40. Das SK, Khaskil S, Mukhopadhyay S, Chakrabarti S (2013) A patient of Russell's viper envenomation presenting with cortical venous thrombosis: An extremely uncommon presentation. J Postgrad Med 59: 235-236.

41. Aissaoui, Hammi, Chkoura (2013) Bull. Soc Pathol Exot 106: 163.

42. Saha K, Saha D, Mondal RRS, Ranjit P Sarkar S, et al. (2013) Cerebral Infarct with Septicemia: An unusual presentation of Snake Bite. IRRMS.

43. Ittyachen AM, Jose MB (2012) Thalamic infarction following a Russell's viper bite. Southeast Asian J Trop Med Public Health 43: 1201-1204.

44. Chani, Abouzahir, Haimeur, DrissiKamili, Mion, et al. Accident vasculairecérébralischémique à la suite d'uneenvenimationvipérine grave au Maroc, traitée par un antivenin inadapté. AnnalesFrançaisesd'Anesthésieet de Réanimation, 31: 82-85.
45. Jeevagan V, Chang T, Gnanathasan CA (2012) Acute ischemic stroke following Hump-nosed viper envenoming; first authenticated case. Thromb 10: 21 .

46. Gupta S, Tewari A, Nair V (2012) Cerebellar infarct with neurogenic pulmonary edema following viper bite. J Neurosci Rural Pract 3: 74-76.

47. Gouda S, Pandit V, Seshadri S, Valsalan R, Vikas M, et al. (2011) Posterior circulation ischemic stroke following Russell's viper envenomation. Ann Indian Acad Neurol 14: 301-303.

48. Deepu D, Hrishikesh S, Suma MT, Zoya V (2011) Posterior fossa infarct following Viper bite: a paradox. J Venom Anim Toxins incl Trop Dis 17: 358360.

49. Sathishkumar (2017). JMSCR.

50. Hsaini Y, Satte A, Balkhi H, Karouache A, Bourezza A, et al. (2010) Infarctus cerebral secondaire à une morsure de vipère. Annales Françaisesd' Anesthésieet de Réanimation 29: 315-316.

51. Machado AS, Barbosa FB, Mello GS, Pardal PPO (2010) Hemorrhagic stroke related to snakebite by bothrops genus: a case report. Rev Soc Bras Med Trop 43: 602-604.

52. Tungpakorn N (2010) Unusual visual loss after snakebite. J Venom Anim Toxins incl Trop Dis 16: 519-523.

53. Narang SK, Paleti S, Azeez Asad MA, Samina T (2009) Acute ischemic infarct in the middle cerebral artery territory following a Russell's viper bite. Neurol India 57: 479-480.

54. Hoskote SS, Iyer VR, Kothari VM, Sanghvi DA (2009) Bilateral anterior cerebral artery infarction following viper bite. J Assoc Physicians India 57 67-69.

55. Gawarammana I, Mendis S, Jeganathan K (2009) Acute ischemic strokes due to bites by Daboiarusselii in Sri Lanka - First authenticated case series. Toxicon 54: 421-428.

56. Mugundhan K, Thruvarutchelvan K, Sivakumar S (2008) Posterior circulation stroke in a young male following snake bite. J Assoc Physicians India 56: 713-714.

57. Prakash S, Mathew C, Bhagat S (2008) Locked-in Syndrome in Snakebite. Assoc Physicians India 56: 121-122.

58. Santos-Soares PC, Bacellar A, Povoas HP, Brito AF, Santana DL, et al. (2007) Stroke and snakebite: case report. Arq Neuropsiquiatr 65: 341-344.

59. Das (2007) Acute ischemic stroke in a Young Girl After Viper Bite. OPJ.

60. Thomas L, Chausson N, Uzan J, Kaidomar S, Vignes R, et al. (2006) Thrombotic stroke following snake bites by the "Fer-de-Lance" Bothropslanceolatus in Martinique despite antivenom treatment: A report of three recent cases. Toxicon 48: 23-28.

61. Merle H, Donnio A, Ayeboua L, Plumelle Y, Smadja D, et al. (2005) Occipital Infarction Releaved by Quadrantanopsia Following Snakebite by BothropsLanceolatus. Am J Trop Med Hyg 73: 583-585.

62. Bhalla A, Jain AP, Banait S, Jajoo UN, Kalantri SP, et al. (2004) Central retinal artery occlusion: an unusual complication of snakebite. J Venom Anim Toxins incl Trop Dis 10: 311-314.

63. Lee, Hong, Kim, Kim, Ko (2004) Cerebral Infarction Following Snakebite. J Korean SocEmerg Med 15: 420-425.

64. Bartholdi D, Selic C, Meier J, Jung HH (2004) Viper snakebite causing symptomatic intracerebral haemorrhage. J Neurol 251: 889-891.

65. Boviatsis EJ, Kouyialis AT, Papatheodorou G, Gavra M, Korfias S, et al. (2003) Multiple Hemorrhagic Brain Infarcts After Viper envenomation. Am J Trop Med Hyg 68: 253-257.

66. Zhang T, Wang Y, Ye P, Liu J, Cheng Y, et al. (2018) Three-dimensional computed tomography reconstructive diagnosis of snakebite-induced cerebral infarction. J Xray Sci Technol 26: 165-169.

67. Hung DZ, Wu ML, Deng JF, Yang DY, Lin-Shiau SY, et al. (2002) Multiple Thrombotic Occlusions of Vessels after Russell's Viper Envenoming. Pharmacol Toxicol 91: 106-110.

68. Diaz (2003) Infarto cerebral y accidenteofídico. Acta Neurol Colomb 19: $75-$ 79.

69. Numeric P, Moravie V, Didier M, Chatot-Henry D, Cirille S et al. (2002) Multiple cerebral infarctions following a snakebite by Bothrops caribbaeus. Am J Trop Med Hyg 67: 287-288.

70. Pinho MAO, Burdmann EA (2001) Fatal Cerebral Hemorrhage and acute renal failure After Young Bothrops Jararcussus snake bite. Renal Failure 23: 269-277. 
Citation: Al-Sadawi M, Mohamadpour M, Zhyvotovska A, Ahmed T, Schechter J, et al. (2019) Cerebrovascular Accident and Snake Envenomation: A Scoping Study. Int J Clin Res Trials 4: 133. doi: https://doi.org/10.15344/2456-8007/2019/133

Page 7 of 7

71. Lee $B C$, Hwang $S H$, Bae $J C$, Kwon $S B$, et al. (2001) Brainstem infarction following Korean viper bite. Neurology 56: 1244-1245.

72. Panicker JN, Madhusudanan S (2000) Cerebral infarction in a young male following viper envenomation. J Assoc Physicians India 48: 744-745.

73. Singh S, Dass A, Jain S, Varma S, Bannerjee AK, et al. (1998) Fatal NonBacterial Thrombotic Endocarditis Following Viperine Bite. Intern Med 37: 342-344.

74. Midyett FA (1998) Neuroradiologic findings in brown snake envenomation: computed tomography demonstration. Australas Radiol 42: 248-249.

75. Cole M (1996) Cerebral Infarct After Rattlesnake Bite. Arch Neurol 53: 957 -

76. Rucavado A, Soto M, Kamiguti AS, Theakston RD, Fox JW, et al Characterization of aspercetin, a platelet aggregating component from the venom of the snake Bothrops asper which induces thrombocytopenia and potentiates metalloproteinase-induced hemorrhage. Thromb Haemost 85 710-715.

77. Kamiguti AS, Cardoso JL (1989) Haemostatic changes caused by the venoms of South American snakes. Toxicon 27: 955-963.

78. Gutierrez JM, Leon G, Tojas G, Lomonte B, Rucavado A, et al. (1989) Neutralization of local tissue damage induced by Bothrops asper (terciopelo) snake venom. Toxicon 36: 1529-1538.

79. Xiong S, Huang C (2018) Synergistic strategies of predominant toxins in snake venoms. Toxicol Lett 287: 142-154.

80. The Lancet (2007) Snake-bite envenoming: a priority neglected tropical disease. Lancet 390: 2. 